\title{
Threats and physical violence in female-dominated workplaces in times of an economic crisis
}

\author{
Hjördís Sigursteinsdóttir \\ School of Business and Science, University of Akureyri, Akureyri, Iceland \\ Guðbjörg Linda Rafnsdóttir \\ Faculty of Social and Human Sciences, University of Iceland, Reykjavik, Iceland, and \\ Thorgerður Einarsdóttir \\ School of Social Science, University of Iceland, Reykjavik, Iceland
}

Threats and physical violence

\begin{abstract}
Purpose - The recent global economic crisis affected workplaces in many countries, raising questions about the employees' situation. While most work-related studies in times of crises focus on job loss and unemployment, this study analyzes workplace violence in the wake of the 2008 economic crisis among municipal employees within care and education.

Design/methodology/approach - Mixed method approach was used for data collection; longitudinal online surveys and focus group interviews were used.

Findings - The prevalence of workplace violence increased between the three time points of the study, in particular in downsized workplaces. A higher proportion of employees working in care were exposed to threats and physical violence than employees in education as clients of employees in care services were more likely to lash out against employees due to cutbacks in services. Focus groups interviews indicated that the causes of increased workplace violence may be due to a spreading effect both from within and outside the workplace. Practical implications - As workplace violence can have serious consequences for the health and well-being of employees, it is important for those who have responsibility for the work environment and occupational health in the workplace to design policies that take these findings into account.

Originality/value - Based on the mixed methods, longitudinal survey and focus group interviews, this study contributes to knowledge on workplace violence in times of economic crises. It shows that the prevalence of workplace violence increased not only directly after the economic collapse but also continued up to five years later.
\end{abstract}

Keywords Downsizing, Gender, Mixed methods, Perpetrators, Threats and violence at work

Paper type Research paper

\section{Introduction}

Although the occurrence of workplace violence is considered to be low in general, Harris and Leather (2012) and Piquero et al. (2013) are among those who show that it can lead to adverse negative outcomes, such as safety concerns, fear, deteriorating job performance and satisfaction, psychological distress, emotional exhaustion and depression. Also, workplace violence can have serious consequences for employees' health and well-being (Boyd, 2002; LeBlanc and Kelloway, 2002) and quality of life (Di Martino et al., 2003). Workplace aggression is neither random nor unpredictable (Barling et al., 2009). However, to be able to prevent violence at work, it is important to understand the causes. As economic crises and downsizing

C Hjördís Sigursteinsdóttir, Guðbjörg Linda Rafnsdóttir and Thorgerður Einarsdóttir. Published by Emerald Publishing Limited. This article is published under the Creative Commons Attribution (CC BY 4.0) licence. Anyone may reproduce, distribute, translate and create derivative works of this article (for both commercial and non-commercial purposes), subject to full attribution to the original publication and authors. The full terms of this licence may be seen at http://creativecommons.org/licences/by/4.0/ legalcode

Received 25 January 2019 Revised 31 July 2019 18 December 2019 Accepted 21 March 2020 
IJWHM 13,4

are recurrent themes and often appear as detrimental to the staff, this article analyzes possible interplay between downsizing and violence. While most studies on the effect of economic crisis on employees focus on job loss and unemployment, the potential increase of violence and threats has received little attention. Therefore, we believe it is important also to shed light on the well-being of the "stayers", that is, those who remain at the workplaces in the wake of the crises. We draw on literature showing that downsizing can create an insecure job environment, which in turn, can diminish employees' power, promote hostile interpersonal behavior (Kulkarni, 2008; Roscigno et al., 2009) and cause psychological distress (Kulkarni, 2008; Snorradóttir et al., 2015; Sweet and Moen, 2012). Barling et al. (2009) point out that evidencebased conclusion about the role of layoffs and downsizing in workplace aggression are needed. Therefore, we aim to fill in this gap in knowledge by exploring potential influence of the global economic crises in 2008 on workplace violence among "survivors".

Even though the economic crisis in 2008 was a global one, Iceland is an interesting country to study; as in October 2008, the three major banks in Iceland collapsed, triggering a deep economic crisis with severe consequences for Icelandic society. The value of the national currency fell dramatically overnight and unemployment increased, followed by rapidly rising inflation; nearly every household, business and organization was affected. Between 2008 and 2009, the currency fell by $25 \%$, and the inflation rate rose from 5.9 to $18.6 \%$, modifying index-linked mortgages. Many Icelanders lost their savings and became burdened with severe debt. According to Statistics Iceland (n.d.), 39\% of households were struggling to make ends meet in 2009 , and this proportion rose to $52 \%$ in 2011 . Furthermore, many workplaces had little choice but to cut back on workers as a way of improving both performance and the economic environment (Sigursteinsdottir and Rafnsdottir, 2015; Snorradóttir et al., 2015). Bernburg (2015) shows that the economic crisis also changed the political context in Iceland as it inspired left-wing activists, social critics and intellectuals to challenge Iceland's right-wing political leadership. These groups organized public meetings in which they framed the crisis as a manifestation of the authorities' unfettered neoliberalism and corruption (Bernburg, 2015).

In mass media, increased discussion was about psychological distress among employees due to downsizing in many workplaces. Even though research on the issue was rare, Sigursteinsdottir and Rafnsdottir (2015) show that the health and well-being of employees of municipalities worsened in the wake of the crises. Furthermore, Snorradóttir et al. (2013b) show that distress among employees in the Icelandic banks had increased one year after the banking collapse, especially in downsizing departments and among women (Snorradóttir et al., 2013a).

Workplaces pertaining to Icelandic municipal governance were not immediately affected by the economic collapse, and the consequences evolved more gradually. In a labor market with a marked gender division, as is the case in Iceland, male-dominated sectors like construction and the financial industry are hit first during a crisis, while the femaledominated public sector is hit harder down the line by downsizing, representing the inevitable result of conservative austerity policies (Karamessini and Rubery, 2013). Prior to the economic collapse, the municipalities had been considered secure workplaces where layoffs were an exception rather than the norm. However, most of the municipalities were progressively forced to cut back services and reduce their wage costs by reducing overtime, instituting hiring freezes, offering voluntary retirement and laying off employees (Samband íslenskra sveitarfélaga, 2011). To a large extent, the services provided by Icelandic municipalities are in the area of welfare and education, and they are carried out by professions in which women are predominant. The nature of their work can largely be characterized as involving client contact and emotional labor (Hochschild, 1983). These are low-status human service jobs in which the employees can be considered especially vulnerable (Lively, 2002; Sharipova et al., 2008). 
Previous studies among Icelandic municipal employees during this economic recession have revealed increased sickness and sickness absence; moreover, they have shown that both mental and physical health of employees deteriorated year by year between 2010 and 2013, with a greater effect in downsized workplaces than those in which no downsizing had occurred (Sigursteinsdóttir and Rafnsdóttir, 2015). Research has also shown that feelings of injustice and anger regarding how layoffs are implemented can lead to workplace aggression (Barling et al., 2009; Brockner, 2006). However, studies on workplace violence and economic crisis and downsizing are scarce (Barling et al., 2009). We aim to further that knowledge by presenting longitudinal balanced panel data and focus group interviews, where we analyze the occurrence of threats and physical violence at work in three different female-dominated workplaces in postcrisis Iceland. The aim is to determine whether there were changes in the extent and nature of threats and physical violence at work among employees in the education system (primary schools and kindergartens) and care service industry (residential homes for elderly and disable people) during the economic crisis, and if so, how employees made sense of their experiences of such developments. The employees in focus are of interest because employees in Icelandic municipalities enjoyed job security prior to the crisis but also because of the close contact these employees have with a large number of families in their communities, such as students and residents of residential homes for elderly and disabled people. It is important to identify where the exposure is highest. Therefore, the aim is also to establish whether there are differences in the levels of threats and physical violence experienced by employees in downsized versus nondownsized workplaces. In addition, an attempt is made to identify the main perpetrators of violence, in order to develop practical knowledge on how to prevent the violence. The results will improve the knowledge about the management of workplace threats and violence in times of economic crisis.

\section{Literature review}

Even if the connection between economic crisis and workplace violence is an underresearched phenomenon, a study in the EU countries on working conditions found that conflict, bullying and violence increased in some European countries in the wake of the economic crisis in 2008 (Eurofound, 2013). This is in line with Tiesman et al. (2013) showing increased occupational violence during economic crisis in Pennsylvania. According to the EU study, rising job insecurity plays an important intermediating role in the effect on stress and harassment. Furthermore, employees reporting substantial restructuring or reorganization are more likely to be exposed to bullying and harassment (Eurofound, 2013).

\section{Violence in health and education sectors}

In line with Josefsson and Ryhammar (2010) and Menckel et al., 2000), the Crime Survey for England and Wales shows that employees in the health and education sectors have one of the highest risks of experiencing violence at work (Buckley, 2013). A recent study by McMahon et al. (2014) among kindergarten and primary school teachers from 48 US states revealed that $44 \%$ of the teachers reported physical attacks and $49 \%$ experienced verbal threats. Men were more likely than women to experience verbal threats (55\% of men and $48 \%$ of women), but no gender differences were found concerning physical attacks. According to Wei et al. (2013), the working environment of educators has a great effect on the risk of work-related violence, with the risk increasing with a higher number of students in class. In addition, working in special education is associated with higher risk.

Bossche et al. (2013) show that increased rates of workplace violence are related to specific characteristics of the labor market (gender, age, sector, etc.) and work environment (client contact frequency, time pressure, control and computer work). They also show that younger individuals, males and those who are working overtime are more likely to be confronted with 
IJWHM 13,4

\section{0}

workplace violence than older individuals, females and those who do not work overtime. The risk of exposure to workplace violence has been reported to be higher in jobs with more amount of social contact, so-called "customer-facing" occupations and may in part be due to the greater emphasis on customer satisfaction in these jobs. This may make people working in sectors with high levels of interaction with the public more exposed to abusive behavior and excessive demands from clients, customers or students (Eurofound, 2013). Piquero et al. (2013) found that the risks of workplace violence vary according to occupational domains, occupational statuses and the nature of victim-aggressor relationships; moreover, they found that factors related to workplace violence appear to be "situational, stress-related, and purposeful— such as the perpetrator being refused a service or request” (p. 389).

\section{Reasons and perpetrators}

Barling et al. (2009) call for evidence-based conclusions about the reasons for workplace violence and the role of layoffs, downsizing and other workplace experiences. They dispel the myth that layoffs are a major predictor of workplace aggression, showing that the perceived fairness with which layoffs are implemented is critical.

Nevertheless, downsizing and layoff should be of a concern for workplace violence as it imposes stress on employees and may affect their health and their ability to work (Brun and Milczarek, 2007). Nevertheless, the impact of downsizing on employees' well-being is a underresearched field (Archibald, 2009). Snorradóttir et al. (2015) show that insecure stayers are the group of employees that experiences the lowest well-being and the worst health in times of downsizing. It does not mean, however, that they are the ones who cause workplace aggression (Barling, 2009).

According to the report of Barling et al. (2009) and Eurofound (2008), workplace violence is more likely to come from clients, customers, patients, students or relatives than from colleagues. Students have been identified as the primary perpetrators of occupational violence against teachers (Gerberich et al., 2011). In line with Swedish studies (Menckel and Viitasara, 2002; Josefsson and Ryhammar, 2010). Tiesman et al. (2013), show that most physical violence against teachers in Pennsylvania occurs during regular school hours, and students represent $93 \%$ of the perpetrators but coworkers or other employees only $7 \%$. Interestingly, the pattern is slightly different regarding nonphysical violence as $73 \%$ of the incidents are perpetrated by students, $15 \%$ by coworkers and $10 \%$ by the students' relatives (Tiesman et al., 2013). However, this is not always the case as Iranian studies suggest that relatives of patients in Iran are the primary perpetrators of workplace violence (Khademloo et al., 2013).

\section{Purpose and research questions}

The aim of the study is to analyze whether and to what extent threats and physical violence changed in the wake of the economic crisis among employees in education and care services in Icelandic municipalities. The study will contribute to the understanding of how workplace changes and downsizing relate to workplace violence. This knowledge is useful as organizations often use downsizing as a managerial tool, especially in times of economic crisis (Snorradóttir et al., 2015). It will add to the relatively small group of studies that has analyzed workplace violence in relation to economic crisis. To our best knowledge, this is the only study using mixed methods in this area, that is, longitudinal survey data and focus groups interviews, to respond to monomethod bias as called for by scholars (Barling et al., 2009).

By threats and physical violence, we refer to any kind of behavior that leads to, or could lead to, physical or psychological harm or suffering, including verbal threats, constraint or arbitrary deprivation of liberty. Balanced panel data (three time-points) and focus group 
interviews were used to collect the data. To our knowledge, these parameters have never been analyzed in connection to the economic crisis.

The research questions are as follows:

$R Q 1$. Was the extent of threats and physical violence in the workplace the same in 2010, 2011 and 2013?

$R Q 2$. Was there any difference in the extent of threats and physical violence between downsized workplaces and those that did not experience downsizing?

$R Q 3$. Who were the perpetrators of threats and physical violence in the workplace?

RQ4. Did the focus group participants experience changes in the level and extent of threats and violence in the wake of the economic crisis?

\section{Materials and methods}

This work is part of a longitudinal study called Health and Well-being of Employees of Municipalities in Iceland in Times of Economic Crisis. The study was approved by the National Bioethics Committee of Iceland (VSN 10-007).

Mixed method approach was used for data collection, online surveys and focus group interviews. The online survey was used for examining the prevalence of workplace violence, while the focus group interviews were used to gather insights into attitudes, feelings, experiences and reactions about a physical assault or verbal threats. The focus group interviews were also designed to obtain information about the workplaces before the crisis as the first measuring point of the online survey is 2010 , about 17 months after the bank collapse.

\section{Online survey and sample}

An online survey was conducted three times - first in February-April 2010 (baseline study), then in May-June 2011 (follow-up study 1), and finally, in February-April 2013 (follow-up study 2). All employees in education (primary school and kindergarten teachers) and care services (skilled and unskilled employees who take care of elderly and disabled people) were included in the survey. In this study, we only use data from the participants who responded to the survey at all three time points to monitor changes for each individual. A total of 5,717 employees in education and care services received an invitation survey in 2010 (baseline). The invitation was accompanied by an information letter emphasizing that the answers would never be traced back to individual participants, and full data confidentiality would be ensured. Three email reminders, along with a motivation letter from managers, were sent to the participants, resulting in a response rate of $79.4 \%$ for the baseline study. Of the 4,542 baseline responders, 4,415 were still working 17 months later, at the time of follow-up study 1 (in 2011), and 3,359 (76\%) responded to the questionnaire a second time after three email reminders and the motivation letter from managers. Of the 3,359 responders in follow-up study 1, 3,258 were still working 20 months later, at the time of follow-up study 2 (2013). Of these, 2,356 responded to the follow-up study 2 questionnaire ( $72 \%$ response rate) after three email reminders and the motivation letter from managers.

\section{Survey questions}

The questionnaire devised for this study was based mainly on two questionnaires, namely, the General Nordic Questionnaire for Psychological and Social Factors at Work (QPS Nordic) and the questionnaire from Health and Well-being of the Icelandic Nation, with additional questions about personnel reductions and internal reorganization. In this study, four 
IJWHM 13,4

\section{2}

questions about workplace violence in the current workplace were used and one question about downsizing.

Four dependent variables were used. First, experience of violence was presented as follows, using simple yes/no questions:

(1) "Have you experienced threats in your current workplace in the past 12 months?"

(2) "Have you experienced physical violence in your current workplace in the past 12 months?"

Then, the perpetrators of physical violence and threats were mapped using the following questions:

(1) "Who was the perpetrator of the threats?"

(2) "Who was the perpetrator of the physical violence?"

For these questions, there were four response options, which were as follows: 1 = manager/ supervisor, $2=$ co-worker, $3=$ student/resident or relatives, and $4=$ other. The participants were free to choose more than one response option.

The independent variables were gender (male/female), workplace (primary school/ kindergarten/residential homes for elderly and disabled people) and downsizing. Downsizing was measured with one yes/no question: "Have employees in your organization been laid off due to the economic crisis that occurred in October 2008?”.

\section{Statistical processing}

Cochran's $Q$ test was conducted to explore the effect of time on threats and physical violence experienced by the employees. A chi-squared test was conducted to explore the differences between occupations and threats and physical violence for each time point of the study. Generalized estimating equations (GEEs) were used for evaluating the effect of downsizing on threats and physical violence over time and at specific time points. There are several advantages to the GEE method when it comes to analyzing longitudinal data; for example, it uses all available data points, provides a method for handling the correlated nature of repeated measurements and accounts for the pattern of change over time. A binomial distribution with a logit link function was used for evaluating the dichotomous dependent variables. We selected a first-order exchangeable correlation structure. The main effects models (time point of the study, downsizing, gender and workplace) and interactions (downsizing*time-point of the study; downsizing*gender; downsizing*workplace) were tested. We obtained the odds ratio (OR), 95\% confidence interval $(\mathrm{CI})$, and associated $p$-value for each predictor in the GEE models. Statistical tests were conducted at a $5 \%$ level of significance. SPSS version 21.0 was used to conduct all the data analyses.

\section{Focus groups}

Seven focus group interviews were conducted in two municipalities, one in the capital area and one outside this area, in January and February 2011. The two municipalities are similar in population size, and both had employee layoffs due to downsizing after the collapse. The purpose of the focus group interviews was complementing the results of the online survey by gaining further insights into the well-being and health of municipal employees in times of economic crisis. The focus groups included employees aged 25 or older who had been working in their current workplace for at least six months before the economic crisis. The personnel manager in each of the two municipalities encouraged concerned employees who were also willing to speak and discuss the topics to participate in the focus groups. The researcher selected participants by workplace (kindergarten, primary school, residential 
homes for elderly and disabled people), age and gender. All the participants signed informed consent forms.

In total, seven focus group interviews were conducted. They consisted of a total of 39 employees (workers and middle management), with 34 women and 5 men, reflecting the gender ratio of the employees. The average age was 42 years (range: $25-58$ years). Three groups consisted of kindergarten teachers, two comprised primary school teachers and finally, one consisted of care workers for elderly and disabled people. Interviews were semistructured, based on a list of predetermined questions about changes in the number and nature of threats and violence in the workplace after the economic collapse. The participants were also encouraged to explore issues they felt were important. When discussing the consequences of the workplace violence, participants were asked if they had anything to add, and one participant explained how his health and well-being at work changed as a result of the workplace violence. Thus, the interviews took the form of a dialog, where the interviewees and their interpretations guided the conversations. Each focus group lasted about 60-90 min. The discussions were recorded and transcribed verbatim.

The coding process was conducted manually, mainly based on a thematic analysis approach for identifying initial codes and a data-driven approach (Creswell, 2014). The focus group notes were read thoroughly multiple times, and a keyword or short sentence was assigned to each statement or paragraph to identify themes and subthemes in the text. Two main themes were developed as follows: (1) the effect of the economic collapse on the employees and (2) influence of the economic collapse on the workplaces. Several subthemes under each theme were developed, such as threats and violence at work. After the initial coding, focus coding was used to recode the transcripts, guided by a specific thematic issue. The objective of focused coding was to identify recurrent patterns and multiple layers of meaning and to delineate variations and interconnections among subthemes within the general topic (Saldaña, 2013). A second coder was not used in the analysis process as the qualitative data were mainly used to support the interpretation of the quantitative data. The quotations were translated from Icelandic into English.

\section{Results}

Most survey participants, $66.4 \%$, were primary school teachers, $24.3 \%$ were kindergarten teachers and $9.3 \%$ worked as carers of elderly or disabled people. All these occupational groups are female-dominated, which is reflected by the higher number of women participating in the survey $(87.4 \%)$. The proportion of female participants varied between the different occupation groups. Among primary school teachers, $84 \%$ were women; among kindergarten teachers, $97 \%$ were women and among carers for elderly and disabled people, $86 \%$ were women. As noted above, the number of men was too small for extensive elaboration of gender differences. Downsizing at the workplace because of the Icelandic bank collapse in 2008, in the form of layoffs, was reported by $27 \%$ of the participants in the baseline survey conducted in 2010. In the follow-up study in $2011,46 \%$ of survey participants reported layoffs at their workplace, and in the 2013 survey, $51 \%$ of survey participants reported that layoffs had taken place at their workplace.

\section{Threats and physical violence}

Table 1 shows the proportion of respondents who had experienced threats in the workplace in 2010, 2011 and 2013.

About $7 \%$ of the participants reported having experienced threats in 2010; the proportions rose to $10.5 \%$ in 2011 and $11 \%$ in 2013 . The differences between the time points of the study were statistically significant according to Cochran's $Q$ test. Most of the threats $(71 \%)$ were 


\begin{tabular}{|c|c|c|c|c|c|c|}
\hline $\begin{array}{l}\text { IJWHM } \\
13,4\end{array}$ & & $\begin{array}{l}\text { First study } \\
\quad(2010) \\
(\%) \\
\end{array}$ & $\begin{array}{c}\text { Follow-up study } \\
1(2011) \\
(\%) \\
\end{array}$ & $\begin{array}{l}\text { Follow-up study } \\
2(2013) \\
(\%) \\
\end{array}$ & $\begin{array}{c}\text { Cochr } \\
\chi^{2}\end{array}$ & $\begin{array}{l}\text { 's } Q \text { test } \\
p \text {-value }\end{array}$ \\
\hline \multirow[b]{2}{*}{384} & Threats & 6.7 & 10.5 & 11.0 & 160.5 & 0.001 \\
\hline & $\begin{array}{l}\text { Gender } \\
\text { Women } \\
\text { Men }\end{array}$ & $\begin{array}{l}6.3 \\
9.8\end{array}$ & $\begin{array}{l}10.0 \\
14.5\end{array}$ & $\begin{array}{l}10.2 \\
16.2\end{array}$ & $\begin{array}{r}130.0 \\
32.3\end{array}$ & $\begin{array}{l}0.001 \\
0.001\end{array}$ \\
\hline & $\begin{array}{l}\text { Workplaces } \\
\text { Kindergartens } \\
\text { Primary schools } \\
\text { Residential homes for elderly and } \\
\text { disabled people }\end{array}$ & $\begin{array}{r}5.6 \\
6.1 \\
14.5\end{array}$ & $\begin{array}{r}8.2 \\
9.3 \\
25.0\end{array}$ & $\begin{array}{r}7.7 \\
10.0 \\
25.9\end{array}$ & $\begin{array}{r}21.3 \\
102.5 \\
38.0\end{array}$ & $\begin{array}{l}0.001 \\
0.001 \\
0.001\end{array}$ \\
\hline & $\begin{array}{l}\text { Downsizing } \\
\text { No } \\
\text { Yes }\end{array}$ & $\begin{array}{l}6.6 \\
7.1\end{array}$ & $\begin{array}{r}9.5 \\
11.8\end{array}$ & $\begin{array}{r}9.4 \\
12.4\end{array}$ & $\begin{array}{r}128.2 \\
37.0\end{array}$ & $\begin{array}{l}0.001 \\
0.001\end{array}$ \\
\hline $\begin{array}{l}\text { Table } 1 \text {. } \\
\text { Proportion of those } \\
\text { who reported having } \\
\text { experienced threats in } \\
2010,2011 \text { and } 2013\end{array}$ & $\begin{array}{l}\text { Note(s): Gender differences: } 20 \\
\chi^{2}(1,2356)=8.9, p<0.05 \\
\text { Workplaces differences: 2010: } \chi \\
\chi^{2}(2,2356)=58.0, p<0.05 \\
\text { Downsizing: } 2013: \chi_{(1,2356)}^{2}=5.3,\end{array}$ & $\begin{array}{l}\chi_{(1,2356)}^{2}= \\
0.05\end{array}$ & $\begin{array}{l}1.4, p<0.05 ; 20 \\
p<0.05 ; 2011:\end{array}$ & $\begin{array}{l}: \chi_{(1,2356)}^{2}=5.2, \\
\chi_{(2,2356)}^{2}=54.5,\end{array}$ & $\begin{array}{l}p<0 \\
p<0\end{array}$ & $\begin{array}{l}\text { 5; 2013: } \\
\text { 5; 2013: }\end{array}$ \\
\hline
\end{tabular}

from students (kindergarten and primary school children) and the residents in residential home for elderly and disabled people. A much lower proportion, $13 \%$, reported that they had experienced threats from relatives of the students or residents in residential home for elderly and disabled people or others, while $12 \%$ reported receiving threats from their supervisors (Table 2).

The proportion of employees in primary schools and employees in residential homes for elderly or disabled people who reported having experienced threats also increased at each time point of the study. Among employees in kindergartens, a different pattern emerged; the proportion of employees in kindergartens who reported having experienced threats increased

\begin{tabular}{|c|c|c|c|c|c|}
\hline & Number & $\begin{array}{l}\text { Manager/ } \\
\text { supervisor } \\
(\%)\end{array}$ & $\begin{array}{c}\text { Co-worker } \\
(\%)\end{array}$ & $\begin{array}{l}\text { Students/ } \\
\text { resident } \\
(\%)\end{array}$ & $\begin{array}{l}\text { Relatives or } \\
\text { others } \\
(\%)\end{array}$ \\
\hline Threats & 312 & 12.2 & 4.2 & 70.8 & 12.8 \\
\hline $\begin{array}{l}\text { Gender } \\
\text { Women } \\
\text { Men }\end{array}$ & $\begin{array}{r}257 \\
55\end{array}$ & $\begin{array}{l}11.3 \\
16.4\end{array}$ & $\begin{array}{l}4.7 \\
1.8\end{array}$ & $\begin{array}{l}71.2 \\
69.1\end{array}$ & $\begin{array}{l}12.8 \\
12.7\end{array}$ \\
\hline $\begin{array}{l}\text { Workplaces }^{\mathrm{a}} \\
\text { Kindergartens } \\
\text { Primary schools } \\
\text { Residential homes for elderly } \\
\text { and disabled people }\end{array}$ & $\begin{array}{r}53 \\
196 \\
63\end{array}$ & $\begin{array}{r}13.2 \\
14.3 \\
4.8\end{array}$ & $\begin{array}{l}5.7 \\
4.1 \\
3.2\end{array}$ & $\begin{array}{l}62.3 \\
66.8 \\
90.5\end{array}$ & $\begin{array}{r}18.8 \\
14.8 \\
1.5\end{array}$ \\
\hline $\begin{array}{l}\text { Downsizing } \\
\text { No } \\
\text { Yes }\end{array}$ & $\begin{array}{l}131 \\
181\end{array}$ & $\begin{array}{r}9.2 \\
14.4\end{array}$ & $\begin{array}{l}5.3 \\
3.3\end{array}$ & $\begin{array}{l}73.3 \\
69.1\end{array}$ & $\begin{array}{l}12.2 \\
13.3\end{array}$ \\
\hline Note(s): ${ }^{\text {a} W o r k p l a c e s ~ d i f f e r e ~}$ & $\chi_{(6,312)}^{2}$ & $7 ; p<0.05$ & & & \\
\hline
\end{tabular}

Table 2.

Reported perpetrators of threats in the workplace
Note(s): ${ }^{a}$ Workplaces differences: $\chi^{2}{ }_{(6,312)}=16.77 ; p<0.05$ 
between 2010 and 2011 but decreased by $0.5 \%$ between 2011 and 2013. However, the proportion of threats was still higher in $2013(7.7 \%)$ than it was in $2010(5.6 \%)$. A somewhat higher proportion of men than women reported having experienced threats in the workplace at all time points of the study, especially men in care services (not shown in Table 2). About $10 \%$ of men reported having experienced threats in 2010 , which is $3.5 \%$ higher than the rate among women. The differences between the proportions of men and women who reported having experienced threats rose to $4.5 \%$ in 2011 and $6.0 \%$ in 2013, when more than $16 \%$ of men reported having experienced threats at work, compared with $10.2 \%$ of women.

There was a significant difference in terms of the perpetrators of the threats between the three different workplace categories (Table 2). Among employees in residential homes for elderly and disabled people who reported having experienced threats at work, more than $90 \%$ of the perpetrators were reported to be the residents. Students were reported to be the perpetrators of threats among $62 \%$ of employees in kindergartens and $67 \%$ of employees in primary schools who reported having experienced threats at work. In addition, managers or supervisors were reported to be the perpetrators of threats in over $14 \%$ of the cases of primary schools and $13 \%$ of cases of kindergartens where the respondents reported having experienced threats at work. Managers or supervisors were the perpetrators less often, in $5 \%$ of the cases reported by those who worked in residential homes for elderly and disable people and reported having experienced threats at work.

The results also showed that participants in workplaces where downsizing had occurred, as well as in workplaces with no downsizing, reported having experienced threats at work. In 2013, a statistically higher proportion of participants in workplaces where downsizing had occurred reported having experienced threats compared with participants in workplaces with no downsizing. The managers or supervisors were reported to be the perpetrators of the threats in more cases in workplaces where downsizing had occurred $(14 \%)$ compared with workplaces with no downsizing $(9 \%)$.

Table 3 shows that more than $7 \%$ of the participants reported having experienced physical violence in the workplace in 2010; the proportions rose to nearly $12 \%$ in 2011 and $13 \%$ in 2013. According to the Cochran's $Q$ test, the differences between the time points of the study were statistically significant. A much higher proportion of physical violence was

\begin{tabular}{|c|c|c|c|c|c|}
\hline & $\begin{array}{c}\text { First study } \\
(2010) \\
(\%)\end{array}$ & $\begin{array}{c}\text { Follow-up study } \\
1(2011) \\
(\%)\end{array}$ & $\begin{array}{c}\text { Follow-up study } \\
2(2013) \\
(\%)\end{array}$ & $\begin{array}{l}\text { Coch } \\
\chi^{2}\end{array}$ & $\begin{array}{l}\text { ran's } Q \\
\text { est } \\
p \text {-value }\end{array}$ \\
\hline Physical violence & 7.2 & 11.7 & 13.0 & 125.0 & 0.001 \\
\hline $\begin{array}{l}\text { Gender } \\
\text { Women } \\
\text { Men }\end{array}$ & $\begin{array}{l}7.1 \\
8.1\end{array}$ & $\begin{array}{l}11.5 \\
13.5\end{array}$ & $\begin{array}{l}12.6 \\
15.5\end{array}$ & $\begin{array}{r}111.0 \\
26.9\end{array}$ & $\begin{array}{l}0.001 \\
0.001\end{array}$ \\
\hline $\begin{array}{l}\text { Workplaces } \\
\text { Kindergartens } \\
\text { Primary schools } \\
\text { Residential homes for elderly and } \\
\text { disable people }\end{array}$ & $\begin{array}{r}1.9 \\
7.5 \\
18.6\end{array}$ & $\begin{array}{r}3.1 \\
12.0 \\
31.8\end{array}$ & $\begin{array}{r}4.7 \\
13.4 \\
31.4\end{array}$ & $\begin{array}{r}7.8 \\
108.9 \\
36.9\end{array}$ & $\begin{array}{l}0.021 \\
0.001 \\
0.001\end{array}$ \\
\hline $\begin{array}{l}\text { Downsizing } \\
\text { No } \\
\text { Yes }\end{array}$ & $\begin{array}{l}7.1 \\
7.4\end{array}$ & $\begin{array}{r}9.6 \\
14.2\end{array}$ & $\begin{array}{l}10.3 \\
15.6\end{array}$ & $\begin{array}{r}119.6 \\
26.9\end{array}$ & $\begin{array}{l}0.001 \\
0.001\end{array}$ \\
\hline
\end{tabular}

Note(s): Workplaces differences: 2010: $\chi_{(2,2356)}^{2}=67.1, p<0.05$; 2011: $\chi_{(2,2356)}^{2}=126.7, p<0.05$; 2013: $\chi_{(2,2356)}^{2}=100.6, p<0.05$

Downsizing: $2011: \chi_{(1,2356)}^{2}=11.3, p<0.05 ; 2013: \chi_{(1,2356)}^{2}=14.3, p<0.05$
Threats and physical violence

385
Table 3. Proportion of those who reported having experienced physical violence in 2010, 2011 and 2013 
IJWHM 13,4

\section{6}

Table 4.

Reported perpetrators of physical violence in the workplace reported among employees in residential homes for elderly and disabled people than in kindergartens or primary schools at each time point. A higher proportion of physical violence was reported by employees in workplaces where downsizing had occurred than in workplaces with no downsizing, but the differences were only statistically significant for 2011 and 2013. The proportions of both women and men who reported having experienced physical violence increased between each time point of the study. Although men reported a higher proportion of physical violence at each time point in the study than women did, the differences were not statistically significant.

As shown in Table 4, the most common perpetrators of physical violence against employees were residents of residential homes for elderly and disabled people (95\%), primary school children $(84 \%)$ and kindergarten children $(79 \%)$. It was much less common to find perpetrators among relatives or others. No coworkers were reported to be perpetrators of physical violence in this study, and supervisors were only found to be perpetrators among kindergarten teachers.

The participants in the focus groups discussed the consequences of the economic collapse for families in general and the workplace. In their opinion, the collapse had affected everyone in one way or another, including students, the elderly and disabled residents. Everyone experienced more frustration, anxiety, anger, helplessness and sadness than before. The participants in all the focus groups also agreed that their current working conditions were characterized by a high pace and heavy workload, increased sickness and sickness absence, violence, and other harassment at work. They talked about the presence of anger, fear, intimidation, threats and physical violence in the workplace although this was less evident among the kindergarten teachers. According to the focus group participants, these situations were much more uncommon for most employees before the economic collapse. Moreover, the participants expressed concern about increased aggression in the workplace and a lack of support from supervisors concerning employees' health, well-being, and safety. They worried that working conditions would not improve in the future and that the current situation, with its high workload due to downsizing, would be the new norm.

The participants in the focus groups reported that the negative effects of threats and physical violence affected their health and well-being at work. In their view, most employees preferred not to talk about the violence, and consequently, they did not report it. Some of them felt ashamed and blamed themselves for the violence, and this was especially the case for

\begin{tabular}{|c|c|c|c|c|c|}
\hline & Number & $\begin{array}{c}\text { Manager/ } \\
\text { supervisor } \\
(\%)\end{array}$ & $\begin{array}{c}\text { Co-worker } \\
(\%)\end{array}$ & $\begin{array}{l}\text { Students/ } \\
\text { residence } \\
(\%)\end{array}$ & $\begin{array}{c}\text { Relatives or } \\
\text { others } \\
(\%)\end{array}$ \\
\hline Physical violence & 364 & 0.6 & - & 85.7 & 13.7 \\
\hline $\begin{array}{l}\text { Gender } \\
\text { Women } \\
\text { Men }\end{array}$ & $\begin{array}{r}310 \\
54\end{array}$ & $\begin{array}{c}0.6 \\
-\end{array}$ & - & $\begin{array}{l}84.5 \\
92.6\end{array}$ & $\begin{array}{r}14.8 \\
7.4\end{array}$ \\
\hline $\begin{array}{l}\text { Workplaces } \\
\text { Kindergartens } \\
\text { Primary schools } \\
\text { Residential homes for elderly } \\
\text { and disabled people }\end{array}$ & $\begin{array}{r}33 \\
253 \\
78\end{array}$ & $\begin{array}{l}6.1 \\
- \\
-\end{array}$ & $\begin{array}{l}- \\
- \\
-\end{array}$ & $\begin{array}{l}78.8 \\
83.8 \\
94.9\end{array}$ & $\begin{array}{r}15.2 \\
16.2 \\
5.1\end{array}$ \\
\hline $\begin{array}{l}\text { Downsizing } \\
\text { No } \\
\text { Yes }\end{array}$ & $\begin{array}{l}142 \\
222\end{array}$ & $\overline{0.9}$ & - & $\begin{array}{l}84.5 \\
86.5\end{array}$ & $\begin{array}{l}15.5 \\
12.6\end{array}$ \\
\hline Note(s): Workplaces differe & ${ }^{2}(4,364)$ & $; p<0.05$ & & & \\
\hline
\end{tabular}


women. They tried to forget the unpleasant experience, pretending that it had not happened to them. One female participant explained, "Victims of threats and physical violence at work are ashamed and usually do not report it; they just try to fight their own battles alone, hoping it will stop." The interviewees pointed out a lack of open discussion about workplace violence and an absence of information on how they should react to such behavior.

According to the focus group participants, women were more exposed to threats and physical violence than men were, resulting in less job satisfaction and diminished health and well-being at work. One of the male participants expressed it this way: "It is like they [students] mostly act out on women, probably because they are more vulnerable than men and being exposed to threats and physical violence upsets women more than men, which must be the purpose of their behavior."

In line with the survey data, the focus group participants said that the students and residents or their relatives were responsible for most of the threats and physical violence.

The interviewees reported that the cutbacks following the economic collapse had affected services provided for residents in residential homes for elderly and disabled people. These cutbacks may have led to anger and frustration among the residents and an increase in violent behavior. One female caregiver for mentally disabled people explained: "In our workplace, you can expect violence at work-it is part of the job. But in 20 years of work, I have never experienced so much anger and frustration among residents, and of course, threats and violence increased correspondingly."

\section{Predicting the likelihood of threats and physical violence}

Table 5 outlines the results of the GEE analyses predicting the likelihood of threats and physical violence in the workplace over time following the economic collapse in October 2008. Downsizing was the most significant single factor affecting the likelihood of threats and physical violence, and it was associated with both phenomena. Respondents at workplaces where downsizing had occurred were $36 \%$ more likely than respondents at workplaces with no downsizing to have experienced threats; controlling for all other factors in the models, these respondents were also 33\% more likely to have experienced physical violence. The time factor was also significantly associated with both threats and physical violence, indicating that participants were more likely to have experienced threats and physical violence in follow-up study $1(\mathrm{OR}=1.55,1.64$, respectively) and follow-up study 2 $(\mathrm{OR}=1.60,1.83$, respectively) than in the first study, controlling for other factors in the models. Employees in both kindergartens and primary schools were less likely to have experienced threats and physical violence in the workplace than employees in residential homes for elderly and disabled people, controlling for other factors. Women were less likely than men to have experienced threats at work $(\mathrm{OR}=0.64)$, controlling for all other factors

\begin{tabular}{lcccr}
\hline & \multicolumn{2}{c}{ Threats } & \multicolumn{2}{c}{ Physical violence } \\
& OR & $95 \% \mathrm{CI}$ & \multicolumn{1}{c}{ OR } & $95 \% \mathrm{CI}$ \\
\hline Intercept & $0.288^{* * * *}$ & $0.19-0.44$ & $0.250^{* * * *}$ & $0.17-0.38$ \\
Downsizing & $1.356^{* * *}$ & $1.10-1.68$ & $1.332^{* *}$ & $1.10-1.62$ \\
Follow-up study 1 & $1.549^{* * *}$ & $1.37-1.76$ & $1.641^{* * *}$ & $1.44-1.87$ \\
Follow-up study 2 & $1.596^{* * *}$ & $1.37-1.86$ & $1.828^{* * *}$ & $1.57-2.13$ \\
Women & $0.637^{* *}$ & $0.46-0.89$ & 0.971 & $0.69-1.37$ \\
Kindergartens & $0.268^{* * *}$ & $0.18-0.41$ & $0.090^{* * *}$ & $0.06-0.14$ \\
Primary schools & $0.282^{* * *}$ & $0.20-0.40$ & $0.286^{* * *}$ & $0.21-0.39$
\end{tabular}

Note(s): ${ }^{*} p<0.05,{ }^{*} p<<0.01,{ }^{* * *} p<0.001$, The reference groups are: first study, men and residential homes for elderly and disabled people
Threats and physical violence

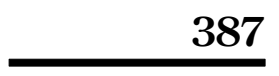


IJWHM 13,4

in the model, but the differences between gender in terms of physical violence were not significant. No interactions were detected (downsizing*time point of the study, downsizing*gender, or downsizing*occupation).

\section{Discussion}

By using longitudinal data and focus group interviews, this study sheds light on possible changes in threats and violence in female-dominated workplaces in times of economic crisis. Even though economic crisis and downsizing are recurrent themes, little is known about connection between economic crisis and workplace violence. Therefore, we ask if the extent of threats and physical violence would be the same in 2010, 2011 and 2013, that is, two, three and five years after Iceland was hit by the global economic crisis. The time factor is important for understanding both the long-term and short-term effects of the crisis on workplace violence, if any. The prevalence of threats and physical violence against employees in municipal workplaces that had undergone downsizing was analyzed and compared with workplaces where no downsizing had occurred. This was done to see if workplaces that had not suffered downsizing were better than others. The focus was also on different types of work and gender.

It is important to note that although the economic situation in Iceland was generally better in 2013 than in 2010, this was not necessarily the case within the municipalities, where the financial cuts and downsizing came later than they did in many other areas of the economy. That can explain why both threats and physical violence increased between the three points of the study even though the last point was five years after the economic collapse. A minor exception was kindergarten, where there was a slight decrease in threats between 2012 and $2013(0.5 \%)$ although the level was still $1.9 \%$ higher in 2013 than it was in 2010 . This indicates that the effects of the economic crisis, such as a fast pace and heavy workload, still remained in the municipalities in 2013, a full five years after the crisis hit Iceland. Even though the threat and violence increased in all workplaces, the situation was worst in downsized workplaces and care services.

According to the Eurofound (2013) report, occupations which demand social interactions are more likely to increase the risk of exposure to various forms of workplace violence. In this respect, the obligations of municipality employees to meet their clients' needs tend to be inherently more demanding and potentially stressful compared to occupations with a limited amount of social contact. The results of this study revealed that employees in care services were more likely to be exposed to threats and physical workplace violence than employees in education were. This finding could be due to the type of work and the nature of the clients, but the results clearly need to be studied further. As Piquero et al. (2013) point out, being refused service or a request can trigger the risk of workplace violence. The focus group interviewees in this study supported that as they reported that the downsizing during the economic crisis had direct negative effects on residents in homes for elderly and disabled people. They described how it led to anger and frustration among the residents and more violent behavior than before. However, the school employees interviewed had similar stories to tell regarding the children's frustration. The results show that performing emotional labor in such an atmosphere can be difficult for the employees, leading to threats and physical violence.

The inconsistencies between men and women regarding threats at the workplace in the quantitative and the qualitative data are somewhat problematic to interpret. Di Martino (2003) argues that women are more exposed to both nonphysical and physical violence, partly due to the fact that the great majority of women still occupy less senior level jobs than men, even in female-dominated workplaces. Tolerance toward violence may differ between various types of occupations and workplaces, in fact, violence in the workplace is sometimes seen as part of the job in the health care sector (Sharipova et al., 2008, p. 575). 
The results from the quantitative data could indicate that men in female-dominated occupations have lower tolerance toward threats and violence and are more prone to admit its existence than women. It could also mean that men working in care services are expected to handle recipients in elderly care and disabled persons who are perceived as violent and aggressive, rather than women. We cannot, based on our data, conclude on that. What is interesting though is that the focus group data concur with the quantitative data. The interviews were conducted with 39 individuals; so they do not allow generalizations about gender patterns among all the employees. However, the different results show that the relationship between gender, threat and violence needs to be studied further.

The strength of the study is that it is based on triangulation of focus group interviews and recent balanced longitudinal data, conducted during the economic crisis (two, three and five years after the banking sector crash in Iceland), when the effects were starting to influence the work organization of the municipalities. All the employees in the studied workplaces received the questionnaire, and the response rate was $72 \%$. With these data, we have a unique chance to follow the individual employees - the "survivors" - and their experience of threats and violence during the crisis. Hitherto, most of the postcrisis analyses of employees' well-being have focused on economic insecurity due to staff layoffs, while the possible increase of violence and threats - the main practical and theoretical contribution of this article - has received little attention.

Researchers have warned the bias of monomethod approach (Barling et al., 2019). As a component in a multimethod design, the focus groups were used to collect data about the reflections of the groups about workplace violence in the wake of the crisis. As the interviews complement the survey data we see this design as one of the strength of the study. The interviewees talked quite openly about their attitudes toward the changes that had occurred in their workplace, their work conditions, higher work pace, heavy workload, worsening working morale and increased threats and violence. They also said their group discussion accurately reflected what was discussed in the employees' cafeteria.

The panel data collection started in 2010, which means that we do not have precrisis data. Therefore, assertions cannot be made about the causal relationship between the crisis on the one hand and workplace violence and harassment on the other. This can be seen as a weakness of the study. However, based on the quantitative and qualitative data, we strongly suggest that the violence may have previously existed at a rate that is unknown to us but escalated after the crisis. Hence, we argue that our data provide valuable insight into the influence of a detrimental development associated with worsening working conditions and downsizing in postcrisis Iceland.

It is difficult to know far enough beforehand when countries will be hit by deep economic crises like the one in 2008. Therefore, it is almost impossible to collect precrisis and postcrisis data without employing long-term panel data. In 2008, such data did not exist concerning the results presented in this study.

Based on the empirical findings, this study contributes to knowledge on the connection between violence and organizational issues, showing that violence increased not only directly after the economic collapse but also up to five years later. The panel data showed that the most significant violence occurred in downsized workplaces. This finding is possibly largely due to organizational factors, such as increased uncertainty, high pace, heavy workload and psychosocial strain in the workplace. This is in line with Kulkarni (2008) and Snorradóttir et al. (2013a, b), who have shown that personnel downsizing can increase the level of stress in workplaces while creating a climate of distrust between employees and managers. However, it is also worth mentioning that we cannot rule out possible spread effects, good or bad, from outside the workplace, as indicated in the focus group interviews. Thus, it is difficult to establish with certainty the extent to which the increased threats and physical violence found in our study can be traced directly to the organization at work, or alternatively, whether the
Threats and physical violence

389 
IJWHM 13,4

situation outside the workplace also had an influence. Nevertheless, the focus group interviews indicated that the causes of increased workplace violence may be due - in addition to more difficult work conditions - to a spreading effect from outside the workplace, such as an increased economic vulnerability among the families of the employees and their clients. Thus, even if we see an increase in workplace violence as an organizational issue in this study, a deep economic crisis, as occurred in Iceland, can also trigger violent workplace behavior that is rooted outside the workplace.

\section{Conclusion}

Nationwide and global economic crises are beyond the control of any individual workplace, but they can have serious consequences for employees. Theoretical and practical discussions on the issue usually focus on staff layoffs in the wake of such crisis, whereas the increase in violence and threats toward employees has received little attention. Violence can have severe consequences for employees and their clients; so it is important for human resource executives and other managers who are responsible for the working environment and well-being of the employees to design policies that consider how violence may increase years after the economic crisis occurs. In addition, such individuals should be aware that not all workplaces are equally affected as downsized workplaces are the most exposed ones. Theories on work organization and well-being need to be developed with this in mind.

\section{References}

Archibald, W.P. (2009), "Globalization, downsizing and insecurity: do we need to upgrade Marx's theory of alienation?", Critical Sociology, Vol. 35 No. 3, pp. 319-342.

Barling, J., Dupré, K.E. and Kelloway, E.K. (2009), "Predicting workplace aggression and violence", Annual Review of Psychology, Vol. 60, pp. 67-92.

Bernburg, J.G. (2015), "Economic crisis and popular protest in Iceland, January 2009: the role of perceived economic loss and political attitudes in protest participation and support", Mobilization, Vol. 20 No. 2, pp. 231-252.

Bossche, S., Taris, T., Houtman, I., Smulders, P. and Kompier, M. (2013), "Workplace violence and the changing nature of work in Europe: trends and risk groups", European Journal of Work and Organizational Psychology, Vol. 22 No. 5, pp. 588-600.

Boyd, C. (2002), "Customer violence and employment health and safety", Work, Employment and Society, Vol. 16 No. 1, pp. 151-169.

Brockner, J. (2006), "Why it's so hard to be fair”, Harvard Business Review, Vol. 84 No. 3, pp. 122-29.

Brun, E. and Milczarek, M. (2007), Expert Forecast on Emerging Psychosocial Risks Related to Occupational Safety and Health, European Agency for Safety and Health at Work, Luxembourg.

Buckley, P. (2013), Violence at Work. Findings From the Crime Survey for England and Wales 2011/12, Health and Safety Executive, London.

Creswell, J.W. (2014), Research Design: Qualitative, Quantitative, and Mixed Methods Approaches, Sage Publications, Thousand Oaks, CA.

Di Martino, V. (2003), "Workplace Violence in the Health Sector: Relationship Between Work Stress and Workplace Violence in the Health Sector", ILO/ICN/WHO/PSI Joint Program on Workplace Violence in the Health Sector, Geneva, available at: http://www.who.int/violence_injury_ prevention/violence/interpersonal/WVstresspaper.pdf (accessed 15 May 2017).

Di Martino, V., Hoel, H. and Cooper, C.L. (2003), "Preventing Violence and Harassment in the Workplace", European Foundation for the Improvement of Living and Working Conditions, Office of Official Publications of the European Communities, Luxembourg. 
Eurofound (2008), Violence in the Education Sector, European Foundation for the Improvement of Living and Working Conditions, Dublin, available at: https://www.eurofound.europa.eu/sites/default/ files/ef_publication/field_ef_document/ef0874en.pdf (accessed 2 June 2019).

Eurofound (2013), Physical and Psychological Violence at the Workplace, Publications Office of the European Union, Luxembourg.

Gerberich, S.G., Nachreiner, N.M., Ryan, A.D., Church, T.R., McGovern, P.M., Geisser, M.S., Mongin, S.J., Watt, G.D., Feda, D.M., Sage, S.K. and Pinder, E.D. (2011), "Violence against educators: a population-based study", Journal of Occupational and Environmental Medicine, Vol. 53 No. 3, pp. 294-302.

Harris, B. and Leather, P. (2012), "Levels and consequences of exposure to service user violence: evidence from a sample of UK social care staff", British Journal of Social Work, Vol. 43 No. 5, pp. 851-869.

Hochschild, R.A. (1983), The Managed Heart: Commercialization of Human Feeling, University of California Press, Berkeley, CA.

Josefsson, K. and Ryhammar, L. (2010), "Threats and violence in Swedish community elderly care", Archives of Gerontology and Geriatrics, Vol. 50, pp. 110-113.

Karamessini, M. and Rubery, J. (Eds.) (2013), Women and Austerity: The Economic Crisis and the Future for Gender Equality, Routledge, Abingdon.

Khademloo, M., Moonesi, F.S. and Gholizade, H. (2013), "Health care violence and abuse towards nurses in hospitals in north of Iran", Global Journal of Health Science, Vol. 5 No. 4, pp. 211-216.

Kulkarni, V.V. (2008), "How does downsizing affect survivors? Insights from the literature", Management and Labour Studies, Vol. 33 No. 2, pp. 241-259.

LeBlanc, M.M. and Kelloway, E.K. (2002), "Predictors and outcomes of workplace violence and aggression", Journal of Applied Psychology, Vol. 8, pp. 444-453.

Lively, K.J. (2002), "Client contact and emotional labor: upsetting the balance and evening the field", Work and Occupations, Vol. 29 No. 2, pp. 198-225.

McMahon, S.D., Martines, A., Espelage, D., Rose, C., Reddy, L.A., Lane, K., Anderman, E.M., Reynolds, C.R., Jones, A. and Brown, V. (2014), "Violence directed against teachers: results from a national survey”, Psychology in the Schools, Vol. 51 No. 7, pp. 753-766.

Menckel, E. and Viitasara, E. (2002), "Threats and violence in Swedish care and welfare: magnitude of the problem and impact on municipal personnel", Scandinavian Journal of Caring Sciences, Vol. 16, pp. 376-385.

Menckel, E., Carter, N. and Viitasara, E. (2000), "Violence towards caregivers of persons with developmental disabilities", Work, Vol. 15 No. 1, pp. 3-8.

Piquero, N.L., Piquero, A.R., Craig, J.M. and Clipper, S.J. (2013), "Assessing research on workplace violence 2000-2012”, Aggression and Violent Behavior, Vol. 18, pp. 383-394.

Roscigno, V.J., Hodson, R. and Lopez, S.H. (2009), "Workplace incivilities: the role of interest conflicts, social closure and organizational chaos", Work, Employment and Society, Vol. 23 No. 4, pp. 747-773.

Saldaña, J. (2013), The Coding Manual for Qualitative Researchers, 2nd ed., Sage, London.

Samband íslenskra sveitarfélaga (2011), Hagrcæingaraðgerðir sveitarfélaga_Fjárhagsácetlanir fyrir árið 2011 [Streamlining Local Government-Budget for 2001], Samband íslenskra sveitarfélaga, Reykjavík.

Sharipova, M., Borg, V. and Hogh, A. (2008), "Prevalence, seriousness and reporting of workrelated violence in the Danish elderly care”, Nordic Journal of Caring Science, Vol. 22, pp. 574-581.

Sigursteinsdóttir, H. and Rafnsdóttir, G.L. (2015), "Sickness and sickness absence of remaining employees in a time of economic crisis: a study among employees of municipalities in Iceland", Social Science \& Medicine, Vol. 132 No. 5, pp. 92-105.

Threats and physical violence 
IJWHM 13,4

\section{2}

Snorradóttir, Á., Rafnsdóttir, G.L., Tómasson, K. and Vilhjálmsson, R. (2013a), "Lay off: the experience of women and men in Iceland's financial sector”, Work, Vol. 47 No. 2, pp. 183-191.

Snorradóttir, Á., Vilhjálmsson, R., Rafnsdóttir, G.L. and Tómasson, K. (2013b), "Financial crisis and collapsed banks: psychological distress and work related factors among surviving employees: a nation-wide study", American Journal of Industrial Medicine, Vol. 56, pp. 1095-1106.

Snorradóttir, Á., Tómasson, K., Vilhjálmsson, R. and Rafnsdóttir, G.L. (2015), "The health and wellbeing of bankers following downsizing: a comparison of stayers and leavers", Work, Employment and Society, Vol. 29 No. 5, pp. 738-756.

Statistics Iceland (n.d.), "Households in financial difficulties by age, 2004-2012", available at: http:/px. hagstofa.is/pxen/pxweb/en/Samfelag/Samfelag__lifskjor_3_fjarhagsstada/VIN07213.px/table/ tableViewLayout1/?rxid=afa49b2a-43ec-49c3-b879-051c45de056d (accessed 15 May 2017).

Sweet, S. and Moen, P. (2012), "Dual earners preparing for job loss: agency, linked lives, and resilience", Work and Occupation, Vol. 39 No. 1, pp. 35-70.

Tiesman, H., Konda, S., Hendricks, S., Mercer, D. and Amandus, H. (2013), "Workplace violence among Pennsylvania education workers: differences among occupations", Journal of Safety Research, Vol. 44, pp. 65-71.

Wei, C., Gerberich, S.G., Alexander, B.H., Andy, D., Ryan, A.D., Nachreiner, N.M. and Mongin, S. (2013), "Work-related violence against educators in Minnesota: rates and risks based on hours exposed", Journal of Safety Research, Vol. 44, pp. 73-85.

\section{About the authors}

Dr Hjördís Sigursteinsdóttir is associate professor in management, School of Business and Science at University of Akureyri. She is $\mathrm{PhD}$ in sociology from the University of Iceland and M.A. in sociology from the same university. Her main research topics are working life, gender, occupational health and well-being at work and rural studies. Hjördís Sigursteinsdóttir is the corresponding author and can be contacted at: hjordis@unak.is

Dr Guðbjörg Linda Rafnsdóttir is prorector of science and professor of sociology. She is a faculty of social and human sciences at University of Iceland. She is $\mathrm{PhD}$ in sociology from the University of Lund, Sweden and M.A. in sociology from the same university. Her main research topics are working life, gender, occupational health and well-being, welfare and virtual work.

Dr Thorgerður Einarsdóttir is professor at faculty of political science - School of Social Science at University of Iceland and chair of gender studies program. She is $\mathrm{PhD}$ in sociology from the University of Göteborg. Her main research topics are professionalism and professionalization, working life balance, globalization and citizenship, labor market, equality and gender equality and feminist theory.

For instructions on how to order reprints of this article, please visit our website:

www.emeraldgrouppublishing.com/licensing/reprints.htm

Or contact us for further details: permissions@emeraldinsight.com 